University of Nebraska - Lincoln

DigitalCommons@University of Nebraska - Lincoln

2013

\title{
Impact of a leptin single nucleotide polymorphism and zilpaterol hydrochloride on growth and carcass characteristics in finishing steers
}

\author{
Paul J. Kononoff \\ University of Nebraska-Lincoln, pkononoff2@unl.edu \\ P. J. Defoor \\ Cactus Research \\ M. J. Engler \\ Cactus Research \\ R. S. Swingle \\ Cactus Research \\ S. T. James \\ Quantum Genetix Canada Inc. \\ See next page for additional authors
}

Follow this and additional works at: https://digitalcommons.unl.edu/animalscifacpub

Kononoff, Paul J.; Defoor, P. J.; Engler, M. J.; Swingle, R. S.; James, S. T.; Deobald, H. M.; Deobald, J. L.; and Marquess, F. L. S., "Impact of a leptin single nucleotide polymorphism and zilpaterol hydrochloride on growth and carcass characteristics in finishing steers" (2013). Faculty Papers and Publications in Animal Science. 787.

https://digitalcommons.unl.edu/animalscifacpub/787

This Article is brought to you for free and open access by the Animal Science Department at DigitalCommons@University of Nebraska - Lincoln. It has been accepted for inclusion in Faculty Papers and Publications in Animal Science by an authorized administrator of DigitalCommons@University of Nebraska - Lincoln. 


\section{Authors}

Paul J. Kononoff, P. J. Defoor, M. J. Engler, R. S. Swingle, S. T. James, H. M. Deobald, J. L. Deobald, and F. L. S. Marquess 


\title{
Impact of a leptin single nucleotide polymorphism and zilpaterol hydrochloride on growth and carcass characteristics in finishing steers
}

\author{
P. J. Kononoff, $* 1,2$ P. J. Defoor, $\uparrow$ M. J. Engler, $\uparrow$ R. S. Swingle, $\uparrow$ S. T. James, $\$$ \\ H. M. Deobald, $\$$ J. L. Deobald, $\$$ and F. L. S. Marquess \\ *Department of Animal Science, University of Nebraska-Lincoln, Lincoln, NE 68582; $†$ Cactus \\ Research, Amarillo, TX 79106; and \$Quantum Genetix Canada Inc., Saskatoon, SK S7N 3R3, Canada
}

\begin{abstract}
A total of 4,178 steers (mean initial BW $=403.9 \pm 16.04 \mathrm{~kg}$ ) were used to test the interactive effects, if any, of leptin R25C genotypes (CC, CT, or $\mathrm{TT})$ and zilpaterol hydrochloride (ZH) feeding duration on growth performance and carcass traits. Steers were blocked by arrival at the feed yard, genotyped for the leptin SNP, allotted to genotype-specific pens (90 steers/pen), and assigned randomly within genotype and block to 0 or $21 \mathrm{~d}$ of dietary ZH. All pens within a block were slaughtered on the same day (132.1 \pm $10.9 \mathrm{~d}$ on feed). Final BW of steers fed $\mathrm{ZH}$ was 6.0 $\mathrm{kg}$ heavier $(P=0.008)$, and $\mathrm{ZH}$-fed steers had greater $(P=0.003)$ ADG than steers not fed $\mathrm{ZH}$. Feeding $\mathrm{ZH}$ decreased DMI in steers with increased frequency of the T allele $(9.67,9.53$, and $9.28 \mathrm{~kg} / \mathrm{d}$ for $\mathrm{CC}, \mathrm{CT}$, and TT, respectively), but DMI increased with the frequency of the T allele $(9.68,9.90$, and $10.1 \mathrm{~kg}$ for CC, CT, and TT, respectively) when ZH was not fed (leptin genotype $\times \mathrm{ZH}, P=0.011)$. At the conclusion of the study, ultrasonic fat was greatest for TT steers $(11.4 \pm 0.28$ $\mathrm{mm})$ and least $(P=0.003)$ for $C \mathrm{C}$ steers $(11.0 \pm 0.25$
\end{abstract}

$\mathrm{mm})$. Regardless of $\mathrm{ZH}$-feeding duration, TT steers produced a greater $(P=0.006)$ percentage of USDA yield grade (YG) 4 or higher carcasses (5.4 vs. $2.7 \%$ ) and a lesser $(P=0.006)$ percentage of YG 1 carcasses (17.7 vs. $26.8 \%$ ) than CC steers. In addition, ZH-fed steers produced a greater $(P<0.001)$ percentage of USDA YG 1 carcasses (25.9 vs. 16.2\%) and a lesser $(P<0.001)$ percentage of YG 4 or higher carcasses (1.6 vs. $6.0 \%$ ) than steers fed the control diet. Marbling scores and the percentage of carcasses grading USDA Choice and Prime were greater in TT than CC steers when fed diets devoid of $\mathrm{ZH}$, but both marbling and quality grades did not differ among leptin genotypes when fed $\mathrm{ZH}$ for $21 \mathrm{~d}$ (leptin genotype $\times \mathrm{ZH}, P \leq 0.03$ ). The amount of HCW gain tended to be less $(P=0.095)$ for steers of the TT genotype $(12.7 \mathrm{~kg})$ than either CC $(16.3 \mathrm{~kg})$ or CT $(17.0 \mathrm{~kg})$ genotypes. Results indicated that leptin R25C genotype impacted most traits associated with fatness whereas feeding $\mathrm{ZH}$ for $21 \mathrm{~d}$ affected HCW and ADG positively but impacted feed intake, marbling, and USDA quality grades negatively.

Key words: feedlot cattle, leptin single nucleotide polymorphism, quality grades, yield grades, zilpaterol hydrochloride

\section{INTRODUCTION}

A cytosine (C) to thymine (T) transitional SNP located in exon 2 of the obese gene (LEP), which codes for the hormone leptin, is associated with fatness $(\mathrm{Bu}-$ chanan et al., 2002) and carcass yield grade in feedlot

\footnotetext{
${ }^{1}$ Participation through consulting agreement with Quantum Genetix, Canada Inc.

${ }^{2}$ Corresponding author: pkononoff2@unl.edu

Received February 21, 2012.

Accepted July 19, 2013.
}

cattle (Kononoff et al., 2005). This functional SNP results from an arginine to cysteine substitution and is commonly abbreviated as LEP R25C. The LEP R25C SNP is believed to impact steer fatness by affecting the function of the leptin molecule.

The beef industry uses $\beta$-adrenergic agonists ( $\beta$-AA) to promote lean tissue growth. These compounds shift nutrient use away from adipose tissue and toward carcass lean tissue (Etherton and Smith, 1991). Two $\beta$-AA approved for use in the U.S. feedlot industry are ractopamine hydrochloride (Optaflexx; Elanco Animal Health, 
Greenfield, IN) and zilpaterol hydrochloride (ZH; Zilmax; Merck Animal Health, De Soto, KS). Although the mechanism of action is not fully elucidated, when $\beta$-AA are administered orally to feedlot cattle, an increase in live BW gain is usually observed (Montgomery et al., 2009a). This increase in lean muscle tissue mass is usually coupled with a decrease in carcass fat (Vasconcelos et al., 2008) because the action of $\beta$-AA is to decrease lipogenesis and increase lipolysis (Mersmann, 1998). Although an array of hormones is believed to be responsible for these effects, these metabolic modulations are at least, in part, achieved through the action of leptin. Leptin is known to affect fatty acid oxidation through $5^{\prime}$ adenosine monophosphate-activated protein kinase-activated protein kinase (AMPK; Minokoshi et al., 2002), a pathway also known to be affected by $\beta$-AA; so, the extent of carcass fatness of beef cattle may depend on the extent to which leptin and $\mathrm{ZH}$ interact. Therefore, the objective of this experiment was to determine the interactive effect, if any, of LEP R25C genotype and $\mathrm{ZH}$ on the growth performance and carcass characteristics of feedlot cattle.

\section{MATERIALS AND METHODS}

\section{Steers Experimental Design and Measures}

All experimental protocols and procedures were in compliance with Federation of Animal Science Societies (FASS, 2010) guidelines for the care and use of cattle in agricultural research. In a randomized complete block design, a total of 4,178 British $\times$ continental crossbred steers (initial BW of $403.9 \pm 16.04 \mathrm{~kg}$ ) were blocked by arrival at the feedyard (Cactus Research, Cactus, TX) into 8 blocks, each consisting of 6 contiguous pens. To fill each block, $900 \pm 100$ steers were procured from a number of commercial sources and subsequently transported to the feedyard. The treatment structure was a $3 \times 2$ factorial, consisting of 3 leptin R25C genotypes (CC, CT, or TT) and dietary inclusion of ZH for $0(\mathbf{0 - Z H})$ or $21 \mathrm{~d}(\mathbf{2 1 - Z H})$. Within a few days after arrival at the feedyard, each steer was uniquely identified with a serial number ear tag, vaccinated with a modified-live viral vaccine (Vista 3; Merck Animal Health), implanted with Revalor-S (120 mg trenbolone acetate +24 mg estradiol; Merck Animal Health), treated for parasites with 1\% Ivomec (Merial Animal Health), and had an ear tissue sample taken for LEP R25C SNP genotype determination. Once leptin genotype was ascertained, genotypes were merged with their respective individual steer identification numbers in an Excel (Microsoft Corp., Redmond, WA) worksheet and sorted into CC, CT, and TT subgroups. Within each of the 8 arrival blocks, there were 2 pens of steers ( 90 steers/pen) for each leptin genotype, and within arrival blocks and genotype, pens were assigned randomly to either 0 or $21 \mathrm{~d}$ of $\mathrm{ZH}$ feeding before slaughter. Yet, for
1 block, the available number of TT genotypes restricted the number and was only 166 (83 steers/pen). Following the spreadsheet randomization process, treatments were assigned randomly to pens within a block, and steers were physically sorted into their respective treatment groups based on their individual steer identification number and the corresponding treatment assignment.

At the time of the physical sort, each steer was weighed individually and given a pen identification tag, and fat thickness was measured ultrasonically. Before feeding the following morning, each pen was group weighed on a platform scale to establish 0 -d BW for performance calculations. At the initiation of the study, cattle were fed a diet that contained $60 \%$ concentrate and gradually transitioned to the finishing diet within $40 \mathrm{~d}$ of the start of the experiment. The finishing diet contained (DM basis) $71.6 \%$ steam flaked corn, $8.5 \%$ corn dried distillers grains and solubles, $10.1 \%$ corn silage, $4.2 \%$ beet molasses blend, $1.6 \%$ animal fat, and $4.0 \%$ mineral and vitamin supplement. This diet is typical of those fed in high plains commercial feedlots and was formulated to meet or exceed nutrient requirements of growing-finishing steers (NRC, 1996). Diets were also formulated, on a DM basis, to contain $33.3 \mathrm{mg} / \mathrm{kg}$ Rumensin (Elanco Animal Health) and $11.0 \mathrm{mg} / \mathrm{kg}$ Tylan (Elanco Animal Health). During the last $21 \mathrm{~d}$ before slaughter, half of the steers were fed $8.3 \mathrm{mg} / \mathrm{kg}$ of ZH. The quantity of feed delivered and removed from feedbunks was recorded daily to calculate DMI and G:F.

Fat thickness was measured ultrasonically using a diagnostic ultrasound unit (SSD-500V; Aloka Co., Ltd., Tokyo, Japan) equipped with a $20-\mathrm{cm}, 3.5-\mathrm{MHz}$ linear array transducer (Aloka Co., Ltd.). Given the nature of the study, these measures could not be taken on exactly the same number of days on the experiment for each steer, but all measures within block were collected on the same day ( $\mathrm{d} 0$, $65 \pm 2.9,105 \pm 9.4$, and $132 \pm 10.0$ ). Ultrasound fat thickness was measured as described by Perkins et al. (1992). The Beef Imaging Analysis (BIA; Designer Genes, Harrison, AR) software program (version 2.1.4) was used to measure 12th rib fat thickness for each image, and the technician either accepted or rejected the calculated thickness of fat. Each steer's fat thickness was recorded on the hard drive and exported to an Excel spreadsheet.

All treatments within a block were slaughtered on the same day $(132.1 \pm 10.9 \mathrm{~d}$ on feed $)$ at a USDA-Food Safety and Inspection Service-inspected facility (Tyson Foods, Inc., Amarillo, TX). After a 36-h chill, carcass quality, and yield grade data (USDA, 1997) were collected by West Texas A\&M University (Canyon, TX) personnel, and USDA quality grades (QG) and yield grades (YG) were assigned by USDA graders. In addition, $\mathrm{HCW}, 12$ th rib fat thickness, LM area, and $\mathrm{KPH}$ were used to calculate YG for each carcass. Marbling, 12th rib fat depth, LM area, and KPH data (USDA, 1997) 
were also recorded for each carcass. Empty body weight (EBW) and the percentage of EBW that was fat (\%EBF) were also calculated as outlined by Tedeschi et al. (2004). Hot carcass weight gain was calculated as $\mathrm{HCW}-$ (initial $\mathrm{BW} \times 0.58)$.

\section{Steer Genotyping}

A modified Y-Tex ear tagger (Y-Tex Corp, Cody, WY) was used to capture a $2 \mathrm{~mm}$ - diameter ear tissue biopsy into a tissue/DNA collection tag (Quantum Genetix Canada Inc, Saskatoon, SK, Canada). Samples were stored at $-20^{\circ} \mathrm{C}$ until the time of extraction. Each collection tag was cut open, tissue was removed and placed in individually labeled 1.5-mL microcentrifuge tubes, and $75 \mu \mathrm{L}$ of fresh $0.2 \mathrm{M} \mathrm{NaOH}$ solution was added. Samples were vortexed for $10 \mathrm{~s}$ before incubation at $65^{\circ} \mathrm{C}$ for $15 \mathrm{~min}$. Samples were then neutralized with $125 \mu \mathrm{L}$ of a solution containing $1.6 \%$ (vol/vol) concentrated HCL and $0.1 M$ Tris. Samples were vortexed and subsequently diluted 1:10 with sterile distilled water in a 96 well microplate. Low yielding samples from the initial extraction method were further purified in the MagNA Pure LC instrument with MagNA Pure LC DNA Isolation Kit I (Roche Applied Science, Mannheim, Germany).

Genotyping was performed in the LightCycler 2.0 real-time PCR instrument (Roche Applied Science). The following oligonucleotide sequences were used: forward primer 5' AAG GAAAAT GCG CTG T 3', reverse primer 5' ACG GTT CTA CCT CGT C 3' (Integrated DNA Technologies, Coalville, IA), anchor probe $5^{\prime}$ GGC CCT ATC TGT CTT ACG GGA GG-fluorescein 3', and sensor probe 5' LC Red640-GTG CCC ATC CGC AAG G-C3 blocker 3' (IT Biochem, Salt Lake City, UT). Each $10-\mu \mathrm{L}$ reaction contained 4.5 $\mu \mathrm{L}$ 2x PCR Master Mix (catalog K0171; Fermentas, Burlington, ON), $0.4 \mu M$ of each forward and reverse primer, $0.15 \mu M$ of each anchor and sensor probe, $2.25 \mathrm{mM} \mathrm{MgCl} 2,200 \mathrm{ng} / \mu \mathrm{L}$ human high density lipoprotein (HDL; Biomedical Technologies Inc., Stoughton, MA), and 3\% (v/v) dimethyl sulfoxide (DMSO; SigmaAldrich, St. Louis, MO). For each reaction, $1.0 \mu \mathrm{L}$ of extracted sample was used as template DNA. The PCR conditions consisted of an initial denaturation at $95^{\circ} \mathrm{C}$ for 2 min followed by an amplification program of 45 cycles of $95^{\circ} \mathrm{C}$ for $2 \mathrm{~s}, 58^{\circ} \mathrm{C}$ for $10 \mathrm{~s}$, and $72^{\circ} \mathrm{C}$ for $10 \mathrm{~s}$. Sample genotypes were determined from a subsequent melting program of $95^{\circ} \mathrm{C}$ for $0 \mathrm{~s}, 40^{\circ} \mathrm{C}$ for $2 \mathrm{~min}$, and continuous fluorescent detection over a temperature increase to $75^{\circ} \mathrm{C}$ at a ramp rate of $0.2^{\circ} \mathrm{C} / \mathrm{s}$. Real-time PCR data were acquired and analyzed using LightCycler software (Roche Applied Science) version 4.0.

\section{Statistical Analysis}

Data were analyzed as a randomized complete block design, with pen as the experimental unit and treatments in a $3 \times 2$ factorial arrangement. The ANOVA was generated using the mixed models procedure of SAS (SAS Inst. Inc., Cary, NC), with treatments and associated interactions considered to be fixed effects whereas pen(block) was considered to be a random effect. The statistical model was $Y_{i j k l}=\mu+\rho_{i}+\alpha_{j}+\beta_{k}+(\alpha \beta)_{j k}+$ $e_{i j k}$, in which $Y_{i j k l}=$ observation for the $j$ th treatment ration within the $i$ th block at the $k$ th measurement, $\rho_{i}=$ random effect of the $i$ th block, $\alpha_{j}=$ fixed effect of the $j$ th $\mathrm{ZH}$ treatment, $\beta_{k}=$ fixed effect for leptin genotype, and $e_{i j k}=$ normally identical and independently distributed error term. The interaction between leptin genotype and $\mathrm{ZH}$ treatment, $(\alpha \beta)_{j k}$, was also included as a fixed effect. The proportion of cattle grading USDA Low Choice or greater was analyzed as a binomial proportion using PROC GLIMMIX of SAS, with block as the random effect. Ultrasound fat thickness data were also analyzed as repeated measures using PROC MIXED of SAS, with day of ultrasonic measurement the repeated variable in the model statement. Least squares means were generated and separation was accomplished via pairwise comparisons of the main or interactive effects (PDIFF option) when a significant $(P \leq 0.05) F$-test was noted. For each steer, a nonlinear exponential model was also fitted to the longitudinal measurements of fat thickness as described by Brethour (2000). The nonlinear regression (NLIN) procedure of SAS was used to fit the nonlinear exponential function $Y=A e^{(k t)}$, in which $Y=$ projected fat, $A=$ the initial fat, $k=$ rate of increase (Brethour, 2000), and $t$ $=$ time in days. Mean model parameters were then tested using the statistical model as described previously.

\section{RESULTS AND DISCUSSION}

\section{Live BW Gain and Fat Thickness Growth}

There were no $(P \geq 0.230)$ leptin genotype $\times \mathrm{ZH}$ interactions for any live performance trait. Initial and final BW $(P \geq 0.528)$ as well as ADG $(P=0.418)$ and $\mathrm{G}: \mathrm{F}(P=$ 0.170 ) were not affected by leptin genotype (Table 1$)$. This is similar to Nkrumah et al. (2004) who tested the impact of LEP R25C SNP and observed that slaughter weight, ADG, and G:F were similar across genotypes. In addition, Montgomery et al. (2009a,b) reported feeding ZH for 21 $\mathrm{d}$ before slaughter increased BW by an average of $6.0 \mathrm{~kg}$. Steers fed $\mathrm{ZH}$ for $21 \mathrm{~d}$ also had greater $(P \leq 0.003)$ ADG and G:F than steers not fed $\mathrm{ZH}$. Moreover, DMI increased $(P<0.05)$ with the frequency of the $\mathrm{T}$ allele over the last $21 \mathrm{~d}$ on feed when fed diets devoid of $\mathrm{ZH}$; however, among ZH-fed steers, DMI actually decreased $(P<0.05)$ with the frequency of the T allele (leptin genotype $\times \mathrm{ZH}, P=0.011$; 
Table 1. Main effects of leptin R25C genotype and zilpaterol hydrochloride (ZH) feeding duration on live steer performance and ultrasound-measured 12 th rib fat thickness

\begin{tabular}{|c|c|c|c|c|c|c|c|c|c|c|}
\hline \multirow[b]{2}{*}{ Item } & \multicolumn{3}{|c|}{ Leptin genotype } & \multirow[b]{2}{*}{ SEM $^{1}$} & \multicolumn{2}{|c|}{$\mathrm{ZH}$ inclusion, ${ }^{1} \mathrm{~d}$} & \multirow[b]{2}{*}{ SEM } & \multicolumn{3}{|c|}{$P$-value ${ }^{2}$} \\
\hline & $\mathrm{CC}$ & $\mathrm{CT}$ & TT & & $0-\mathrm{ZH}$ & $21-\mathrm{ZH}$ & & GT & $\mathrm{ZH}$ & I \\
\hline Number of pens & 16 & 16 & 16 & & 24 & 24 & & & & \\
\hline Final BW, $\mathrm{kg}$ & 607.6 & 608.5 & 606.7 & 5.51 & $604.6^{\mathrm{a}}$ & $610.6^{\mathrm{b}}$ & 5.40 & 0.792 & 0.008 & 0.389 \\
\hline $\mathrm{ADG}, \mathrm{kg} / \mathrm{d}$ & 1.62 & 1.63 & 1.60 & 0.027 & $1.59^{\mathrm{a}}$ & $1.65^{\mathrm{b}}$ & 0.025 & 0.418 & 0.003 & 0.404 \\
\hline $\mathrm{DMI},{ }^{3} \mathrm{~kg} / \mathrm{d}$ & 10.2 & 10.3 & 10.3 & 0.100 & 10.3 & 10.2 & 0.095 & 0.330 & 0.124 & 0.230 \\
\hline \multicolumn{11}{|c|}{ Ultrasound fat thickness, ${ }^{4} \mathrm{~mm}$} \\
\hline $\mathrm{d} 0$ & $3.48^{\mathrm{a}}$ & $3.52^{\mathrm{ab}}$ & $3.61^{\mathrm{b}}$ & 0.126 & 3.55 & 3.53 & 0.124 & 0.050 & 0.611 & 0.909 \\
\hline d 65 & $7.58^{\mathrm{a}}$ & $7.86^{\mathrm{b}}$ & $8.02^{\mathrm{b}}$ & 0.173 & 7.92 & 7.72 & 0.166 & 0.004 & 0.061 & 0.689 \\
\hline d 105 & $9.73^{\mathrm{a}}$ & $9.90^{\mathrm{ab}}$ & $10.31^{b}$ & 0.171 & $10.08^{\mathrm{a}}$ & $9.88^{\mathrm{b}}$ & 0.164 & $<0.001$ & 0.055 & 0.790 \\
\hline d 132 & $11.0^{\mathrm{a}}$ & $11.2^{\mathrm{ab}}$ & $11.5^{\mathrm{b}}$ & 0.254 & $11.4^{\mathrm{a}}$ & $11.0^{\mathrm{b}}$ & 0.254 & 0.003 & 0.002 & 0.964 \\
\hline Mean & $9.19^{\mathrm{a}}$ & $9.42^{\mathrm{b}}$ & $9.72^{\mathrm{b}}$ & 0.148 & $9.32^{\mathrm{a}}$ & $9.58^{\mathrm{b}}$ & 0.141 & $<0.001$ & 0.004 & 0.733 \\
\hline
\end{tabular}

a,b Within a row and main effect of leptin genotype, least squares means lacking a common superscript letter differ, $P<0.05$.

${ }^{1}$ Dietary inclusion of zilpaterol hydrochloride for $0(0-\mathrm{ZH})$ or $21 \mathrm{~d}(21-\mathrm{ZH})$.

${ }^{2}$ Probability value for the main effect of leptin genotype (GT) and duration of ZH feeding (ZH) as well as the interactive (I) effect of GT and ZH.

${ }^{3}$ Daily DMI recorded before dietary administration of ZH.

${ }^{4}$ Analyzed as a repeated measure using the 4 observation $\mathrm{d}(0 \pm 0.0,65 \pm 2.9,105 \pm 9.4$, and $132 \pm 10.0 \mathrm{~d})$.

${ }^{5}$ Average fat gain $(\mathrm{AFG})=(\mathrm{d}-132$ fat thickness $-\mathrm{d}-0$ fat thickness $) /$ total days on feed.

Fig. 1). Differences between 0 and $21 \mathrm{~d}$ of $\mathrm{ZH}$ feeding among the genotypes were $0.82,0.37$, and $0.01 \mathrm{~kg} / \mathrm{d}$ for steers with TT CT, and CC genotypes, respectively. When ZH was fed for $40 \mathrm{~d}$ Vasconcelos et al. (2008) observed a reduction in DMI of $0.40 \mathrm{~kg} / \mathrm{d}$. Interestingly in the current experiment, an interaction between leptin genotype and $\mathrm{ZH}$ status was observed on DMI over the last $21 \mathrm{~d}$ of the experiment (Fig. 1). The effect of the T allele on DMI in 0-ZH fed steers was expected given that circulating levels of leptin are believed to downregulate feed intake (Houseknecht et al., 1998). Furthermore, if ZH impacts DMI through either a direct tissue effect or an indirect endocrine effect as described by Montgomery et al. (2009a), it is also expected that it would interact with a functional leptin SNP.

Ultrasound-measured fat thickness increased $(P \leq$ 0.05 ) each of the 4 measurement days by leptin genotype, and this effect was independent of ZH feeding (Table 1). At the conclusion of the feeding period, fat thickness $(P$ $=0.003$ ) was greatest in TT steers and least in CC steers and these observations, which further supports the positive relationship between $\mathrm{T}$ allele and fatness observed in mature beef bulls (Buchanan et al., 2002) and feeder cattle (Nkrumah et al., 2004); however, this relationship had not been examined in finishing cattle fed $\mathrm{ZH}$. The rate of fat gain (AFG) also increased $(P=0.027)$ with the frequency of the $\mathrm{T}$ allele. These results are similar to those of Nkrumah et al. (2004), who noted that, when fitted to a linear model, the rate of fat deposition increased with the presence of the $\mathrm{T}$ allele. Collectively, these results further support the suggestion that a SNP in the leptin gene results in functional effects. Although the nature of these effects are not completely understood, it has been speculated that AA change in the leptin molecule may impede receptor binding of leptin or that the unpaired cysteine in the molecule may destabilize the disulfide bridge and affect biological function and ultimately feed intake or energy balance (Buchanan et al., 2002, 2003).

By comparing control and $\mathrm{ZH}$ fat thickness values within genotypes in Table 1, mean ultrasound fat thickness at the final (fourth) measurement was reduced $(P=0.002)$

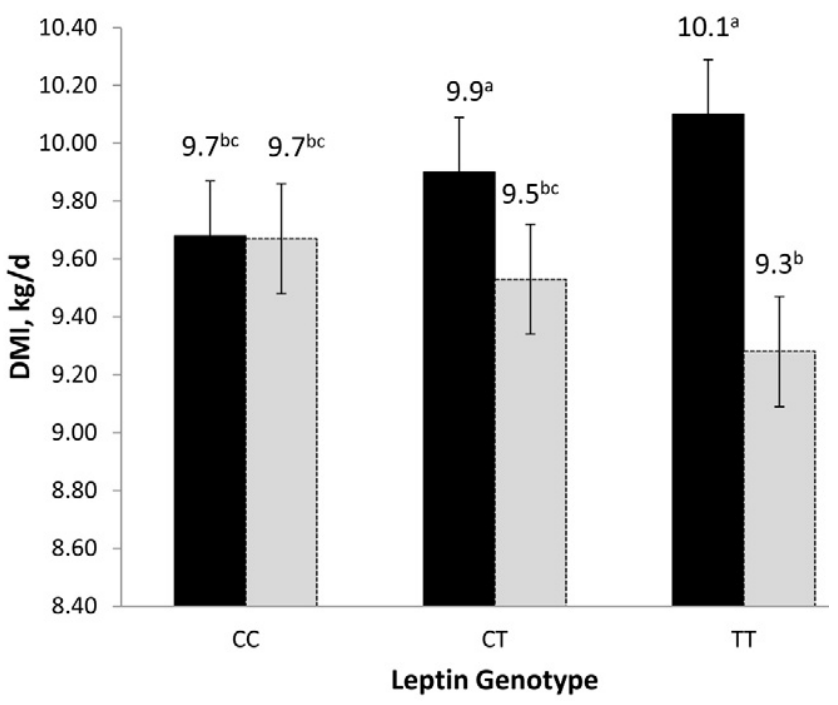

Figure 1. The interactive effect $(P=0.011)$ of leptin genotype (CC, CT, and TT) and dietary inclusion of zilpaterol hydrochloride for $0 \mathrm{~d}$ (black bars) or $21 \mathrm{~d}$ (grey bars) before slaughter on DMI (kg/d) of feedlot steers. Means lacking a common superscript letter differ, $P<0.05$. 
Table 2. Main effects of leptin R25C genotype and zilpaterol hydrochloride $(\mathrm{ZH})$ on estimated parameters of an exponential function relating ultrasound-measured fat thickness deposition to days on feed

\begin{tabular}{|c|c|c|c|c|c|c|c|c|c|c|}
\hline \multirow[b]{2}{*}{ Item } & \multicolumn{3}{|c|}{ Leptin genotype } & \multirow[b]{2}{*}{ SEM } & \multicolumn{2}{|c|}{$\mathrm{ZH}$ inclusion, ${ }^{1} \mathrm{~d}$} & \multirow[b]{2}{*}{ SEM } & \multicolumn{3}{|c|}{$P$-value ${ }^{2}$} \\
\hline & $\mathrm{CC}$ & $\mathrm{CT}$ & TT & & $0-\mathrm{ZH}$ & $21-\mathrm{ZH}$ & & GT & $\mathrm{ZH}$ & I \\
\hline Initial fat thickness, $A,{ }^{3} \mathrm{~mm}$ & $3.77^{\mathrm{a}}$ & $3.87^{\mathrm{a}}$ & $3.99^{\mathrm{b}}$ & 0.118 & 3.90 & 3.86 & 0.116 & 0.003 & 0.390 & 0.760 \\
\hline Days to $10 \mathrm{~mm}$ of fat thickness ${ }^{4}$ & $128^{\mathrm{a}}$ & $125^{\mathrm{b}}$ & $122^{\mathrm{b}}$ & 5.03 & $123^{\mathrm{a}}$ & $129^{b}$ & 4.98 & 0.002 & 0.003 & 0.984 \\
\hline Days to $12 \mathrm{~mm}$ of fat thickness ${ }^{4}$ & $153^{\mathrm{a}}$ & $149^{\mathrm{b}}$ & $146^{\mathrm{b}}$ & 5.51 & $147^{\mathrm{a}}$ & $152^{\mathrm{b}}$ & 5.46 & 0.003 & 0.001 & 0.933 \\
\hline Days to $14 \mathrm{~mm}$ of fat thickness ${ }^{4}$ & $173^{\mathrm{a}}$ & $169^{\mathrm{ab}}$ & $167^{\mathrm{b}}$ & 5.95 & $167^{\mathrm{a}}$ & $172^{\mathrm{b}}$ & 5.91 & 0.007 & 0.001 & 0.877 \\
\hline
\end{tabular}

a,b Within a row and main effect of leptin genotype, least squares means lacking a common superscript letter differ, $P<0.05$.

${ }^{1}$ Dietary inclusion of zilpaterol hydrochloride for $0(0-\mathrm{ZH})$ or $21 \mathrm{~d}(21-\mathrm{ZH})$.

${ }^{2}$ Probability value for the main effect of leptin genotype (GT) and duration of ZH feeding (ZH) as well as the interactive (I) effect of GT and ZH.

${ }^{3}$ Nonlinear parameter fitted for each individual steer.

${ }^{4}$ Computed days to 10,12 , and $14 \mathrm{~mm}$ of fat thickness based in fitted parameters as extrapolated by the following equation: $y=[\ln (10)-\ln (x)] / k$, in which $y$ is the adjustment from the initial day on feed, $x$ is the fat thickness measure at the beginning of the experimental period, and $k$ is the rate of increase (Brethour, 2000).

by $0.4 \mathrm{~mm}$ in both CT and TT cattle and $0.5 \mathrm{~mm}$ in CC cattle, by ZH feeding (Table 1). The reduction is similar to the impact of ZH on carcass 12th rib fat measures reported previously by Montgomery et al. (2009b). It should be noted that there was a modest difference $(P=0.055)$ in fat thickness between $\mathrm{ZH}$ treatment groups before administration of the drug. Although the reason for this differences is largely unknown, it is important to note the mean differences observed on $\mathrm{d} 2$ and 3 ( 0.18 and $0.22 \mathrm{~mm}$, respectively) were less than that observed on $\mathrm{d} 4(0.40 \mathrm{~mm})$; thus, it is plausible that $\mathrm{ZH}$ negatively affects accumulation of fat thickness.

Brethour (2000) noted that $25 \%$ of feeder cattle were marketed too fat whereas another $25 \%$ were marketed too lean, indicating that half of all the feeder cattle sold in the United States were fed either too long or not long enough. Furthermore, Brethour (2000) suggested that ultrasound technology could be used to rapidly estimate carcass characteristics on live cattle and project the time needed to reach a given level of fatness. Therefore, the effects of leptin genotype and $\mathrm{ZH}$ feeding duration on the relative rates of fat accretion/deposition were further tested by fitting data to an exponential function on serial within-steer measurements $\left[Y=A e_{(k t)}\right.$; Brethour, 2000]. The observed rate coefficients (Table 2) were slightly less than those of Brethour (2000), who reported fat thickness rate coefficients of 0.0117 for a group of 137 Limousin and Simmental steers and 0.0096 for a group of 292 Angus and Angus $\times$ Hereford steers. In the present study, patterns of fat accretion were found to be dependent on leptin genotypes and administration of $\mathrm{ZH}$. With respect to leptin genotype, initial fat thickness (parameter $A$ ) was greatest in steers homozygous for the T allele $(3.99 \mathrm{~mm})$ compared to either the CC $(3.77 \mathrm{~mm})$ or CT $(3.87 \mathrm{~mm})$ genotypes whereas the rate of fat thickness growth $(k)$ was not $(P=0.771)$ affected by leptin genotype. The time projected to reach 10,12 , and $14 \mathrm{~mm}$ of 12 th rib fat thickness was calculated and differed by genotype, with TT steers possible reaching the target fat endpoint of $10 \mathrm{~mm} 6 \mathrm{~d}$ earlier $(P<0.01)$ than
$\mathrm{CC}$ steers. Rate of fat growth $(k)$ was reduced by $\mathrm{ZH}(P=$ $0.021)$, and $\mathrm{ZH}$ treatment would increase $(P=0.003)$ the time to reach $10 \mathrm{~mm}$ of 12 th rib fat thickness as much as 6 d. Similarly, patterns were observed in projections for reaching 12 and $14 \mathrm{~mm}$ of fat. These latter observations should be treated with caution because these projections extend beyond the time cattle were on feed $(132 \pm 10.9 \mathrm{~d})$ in the current study and projections outside of the modeled range may be unreliable.

\section{Carcass Characteristics and Grades}

Even though HCW did not $(P=0.432)$ differ among leptin genotypes, carcasses from TT steers were fatter $(P=0.009)$ than carcasses from $\mathrm{CC}$ steers, regardless of $\mathrm{ZH}$ feeding (Table 3). Furthermore, neither LM area $(P=$ $0.930), \mathrm{KPH}$ fat $(P=0.675)$, nor calculated $\mathrm{YG}(P=0.284)$ were affected by leptin genotype; however, the percentage of YG 1 carcasses was greater $(P<0.001)$ and the percentage of YG 4 or greater carcasses was less $(P=0.006)$ from $\mathrm{CC}$ steers than $\mathrm{CT}$ and TT steers. Additionally, 12th rib fat and calculated empty body fat (EBF) were increased $(P \leq 0.009)$ with the frequency of the T allele. Regardless of leptin genotype, feeding $\mathrm{ZH}$ for the last $21 \mathrm{~d}$ before slaughter produced heavier $(P<0.001) \mathrm{HCW}$, larger $(P<$ $0.001) \mathrm{LM}$ areas, less $(P=0.001)$ fat opposite the 12th rib, and lower $(P<0.001)$ calculated YG (Table 3$)$. Moreover, $\mathrm{ZH}$ feeding increased $(P \leq 0.006)$ the percentages of $Y \mathrm{G} 1$ and 2 carcasses and decreased $(P<0.001)$ the percentage of YG 3 and 4 carcasses. Mean calculated YG was also less in carcasses from steers fed $\mathrm{ZH}(P<0.001)$ regardless of leptin genotype. The reduction in $\mathrm{YG}$ in $\mathrm{ZH}$ fed cattle is consistent with the results of Montgomery et al. (2009a,b) and Vasconcelos et al. (2008) and supports the theory that $\mathrm{ZH}$ stimulates lipolysis and may also decrease fatty acid synthesis (Mersmann, 1998). When ZH was fed for $20 \mathrm{~d}$, these investigators observed that $\mathrm{ZH}$ reduced calculated YG by approximately 0.4 units. The dramatic response on 
Table 3. Main effects for leptin genotype and zilpaterol hydrochloride $(\mathrm{ZH})$ on carcass characteristics

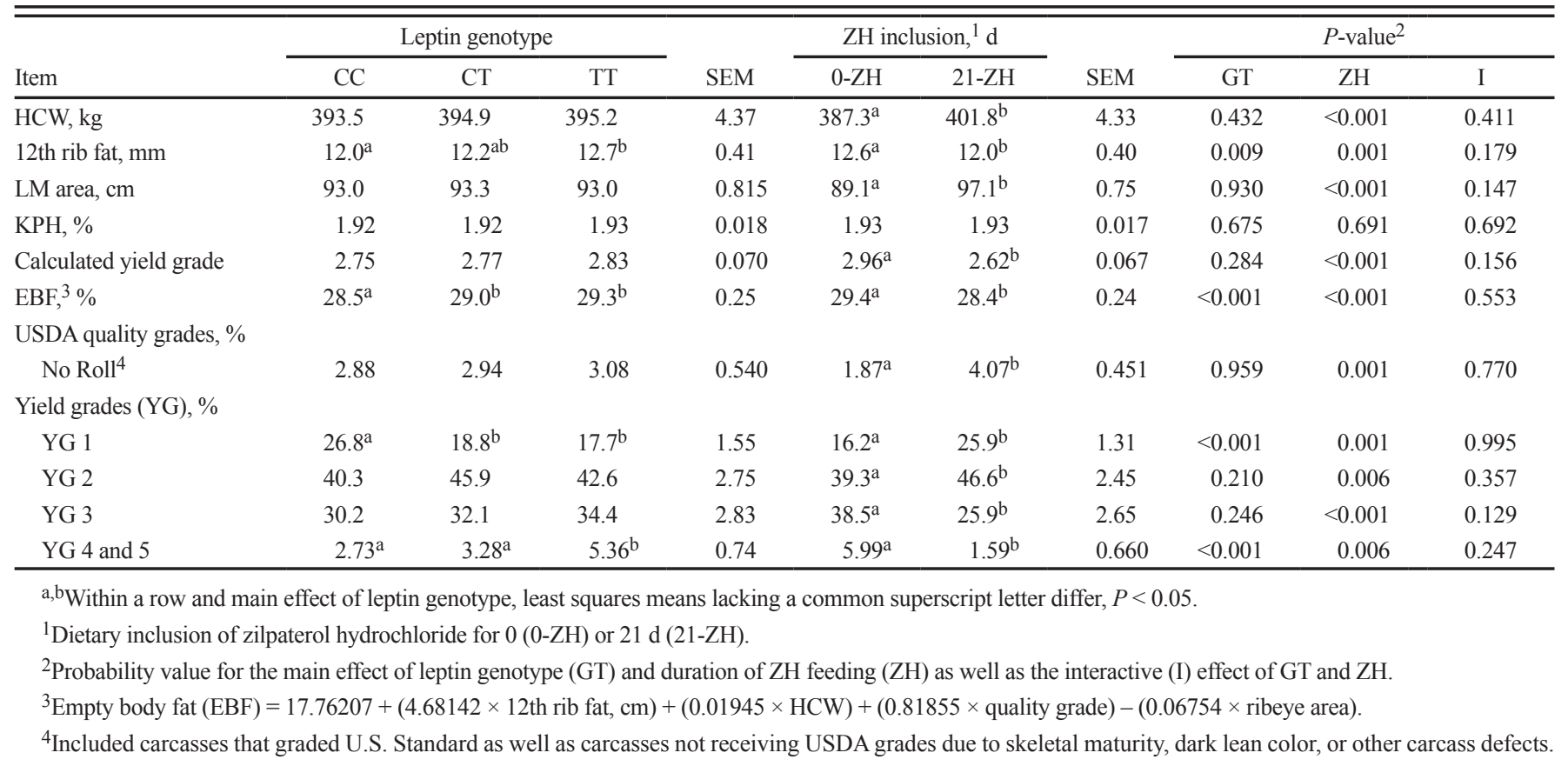

HCW and LM area observed in the current study demonstrated the potent impact of $\mathrm{ZH}$ on muscle growth. In the case of $\mathrm{HCW}$, the response of $14.5 \mathrm{~kg}$ observed in the current study is similar to that observed on Montgomery et al. (2009a,b), Scramlin et al. (2010), and McEvers et al. (2012) but less than that reported by Vasconcelos et al. (2008). The response of LM area observed in the current study was similar that that observed by Montgomery et al. (2009a) but greater that that reported by McEvers et al. (2012).

Feeding ZH for the last $21 \mathrm{~d}$ before slaughter reduced marbling scores and mean QG in CT and TT steers, but marbling scores and QG of CC steers were not affected by $\mathrm{ZH}$ feeding (leptin genotype $\times \mathrm{ZH}, P=0.027$; Table 4). In addition, the percentage of carcasses receiving a $Q G$ of U.S. Choice and U.S. Prime increased as the frequency of the $T$ allele increased when steers were fed diets devoid of $\mathrm{ZH}$ but in $\mathrm{ZH}$-fed cattle, but there was no difference in the percentage of U.S. Choice or higher carcasses among the genotypes (leptin genotype $\times \mathrm{ZH}, P<0.001$; Table 4) Conversely, CT and TT steers fed ZH produced a greater percentage of U.S. Select grade carcasses than all 3 leptin genotypes fed the control diet (leptin genotype $\times \mathrm{ZH}, P$ $<0.001)$. Although feeding $\mathrm{ZH}$ has been demonstrated to decrease marbling scores (Montgomery et al., 2009a; McEvers et al., 2012; Vasconcelos et al., 2008) and the proportion of carcasses grading USDA Choice or higher (Montgomery et al., 2009b), the observation that the response may be dependent on the leptin R25C genotype has not been reported previously. The effects of $\mathrm{ZH}$ on QG are very similar to the interactive pattern observed on DMI, and it was hypothesized that the effects on carcass QG were largely driven by the impacts on feed intake and energy status, which is known to affect QG positively (Hicks et al., 1990; Cruz et al., 2010). There was a tendency ( $P$ $=0.095$ ) for an interaction between leptin genotype and $\mathrm{ZH}$ on calculated HCW gain (data not shown). The differences within genotype between $0-\mathrm{ZH}$ and $21-\mathrm{ZH}$ on $\mathrm{HCW}$

Table 4. The effects of leptin genotype and zilpaterol hydrochloride $(\mathrm{ZH})$ on carcass characteristics and grades ${ }^{1}$

\begin{tabular}{|c|c|c|c|c|c|c|c|c|c|c|}
\hline \multirow[b]{2}{*}{ Item } & \multicolumn{2}{|c|}{ CC genotype } & \multicolumn{2}{|c|}{ CT genotype } & \multicolumn{2}{|c|}{ TT genotype } & \multirow[b]{2}{*}{ SEM } & \multicolumn{3}{|c|}{$P$-value ${ }^{2}$} \\
\hline & $0-\mathrm{ZH}$ & $21-\mathrm{ZH}$ & $0-\mathrm{ZH}$ & $21-\mathrm{ZH}$ & $0-\mathrm{ZH}$ & $21-\mathrm{ZH}$ & & GT & $\mathrm{ZH}$ & I \\
\hline Marbling score ${ }^{3}$ & $41.4^{\mathrm{a}}$ & $40.7^{\mathrm{a}}$ & $42.9^{\mathrm{b}}$ & $40.7^{\mathrm{a}}$ & $43.4^{\mathrm{b}}$ & $40.9^{\mathrm{a}}$ & 8.40 & 0.012 & $<0.001$ & 0.027 \\
\hline U.S. Choice or higher & $47.9^{b c}$ & $46.2^{\mathrm{bc}}$ & $59.2^{\mathrm{a}}$ & $42.3^{\mathrm{bc}}$ & $63.8^{\mathrm{a}}$ & $42.8^{\mathrm{b}}$ & 3.73 & 0.042 & $<0.001$ & $<0.001$ \\
\hline U.S. Select & $49.7^{\mathrm{b}}$ & $49.7^{\mathrm{bc}}$ & $38.0^{\mathrm{ab}}$ & $53.2^{\mathrm{c}}$ & $34.3^{\mathrm{a}}$ & $52.7^{\mathrm{c}}$ & 3.42 & 0.012 & $<0.001$ & $<0.001$ \\
\hline
\end{tabular}

${ }^{\mathrm{a}-\mathrm{c}}$ Within a row and main effect of leptin genotype, least squares means lacking a common superscript letter differ, $P<0.05$.

${ }^{1}$ Dietary inclusion of zilpaterol hydrochloride for $0(0-\mathrm{ZH})$ or $21 \mathrm{~d}(21-\mathrm{ZH})$.

${ }^{2}$ Probability value for the main effect of leptin genotype (GT) and duration of ZH feeding (ZH) as well as the interactive (I) effect of GT and ZH.

${ }^{3}$ Marbling score: based on the following scale: $10=$ practically devoid, $20=$ traces, $30=$ slight, $40=$ small, $50=$ modest, $60=$ moderate, $70=$ slightly abundant, $80=$ moderately abundant, and $90=$ abundant. 
gain tended to be less for steers of the TT genotype (12.7 $\mathrm{kg}$ ) compared to either CC or CT genotypes (16.3 and $17.0 \mathrm{~kg}$, respectively). The gain in BW was less than the gain in HCW, which was observed by Montgomery et al. (2009b) and Holland et al. (2009), who suggested that this difference was due to reductions in DMI and, ultimately, gut fill; however, result of the current study indicated that reductions in DMI of $\mathrm{ZH}$-fed steers represented only a small contribution to $\mathrm{HCW}$. Thus, the reason that $\mathrm{HCW}$ gain exceeded BW gain may be either a shift in mass from noncarcass to carcass tissue or more substrate repartitioning in carcass rather than noncarcass tissue (Montgomery et al., 2009b).

Results of the present study support the hypothesis that the extent of carcass fatness of beef cattle may depend on the proper function of leptin and administration of $\mathrm{ZH}$. Although the mechanism of this relationship in feedlot cattle has not been clearly established, it has been suggested that the mechanism is at least in part because of the action of both leptin (Minokoshi et al., 2002) and ZH (Tokach et al., 2010) on AMPK and ultimately fatty acid oxidation.

\section{LITERATURE CITED}

Brethour, J. R. 2000. Using serial ultrasound measures to generate models of marbling and backfat thickness changes in feedlot cattle. J. Anim. Sci. 78:2055-2061.

Buchanan, F. C., C. J. Fitzsimmons, A. G. Van Kessel, T. D. Thue, and S. M. Schmutz. 2002. A missense mutation in the bovine leptin gene affects carcass fat content and mRNA levels. Genet. Sel. Evol. 34:105-106.

Buchanan, F. C., A. G. Van Kessel, C. Waldner, D. A. Christensen, B. Laarveld, and S. M. Schmutz. 2003. An association between a leptin single nucleotide polymorphism and milk and protein yield. J. Dairy Sci. 86:3164-3166.

Cruz, G. D., J. A. Rodriguez-Sanchez, J. W. Oltjen, and R. D. Sainz. 2010. Performance, residual feed intake, digestibility, carcass traits, and profitability of Angus-Hereford steers housed in individual or group pens. J. Anim. Sci. 88:324-329.

Etherton, T. D., and S. B. Smith. 1991. Somatotropin and beta-agonists: Their efficacy and mechanisms of action. J. Anim. Sci. 69:2-26.

Federation of Animal Science Societies (FASS). 2010. Guide for the care and use of agricultural animals in research and teaching. 3rd ed. FASS, Champaign, IL.

Hicks, R. B., F. N. Owens, D. R. Gill, J. J. Martin, and C. A. Strasia. 1990. Effects of controlled feed intake on performance and carcass characteristics of feedlot steers. J. Anim. Sci. 68:233-244.

Holland, B. P., C. R. Krehbiel, G. G. Hilton, M. N. Streeter, D. L. VanOverbeke, J. N. Shook, D. L. Step, L. O. Burciaga-Robles, D. R. Stein, D. A. Yates, J. P. Hutcheson, W. T. Nichols, and J. L. Montgomery. 2009. Effect of extended withdrawal of zilpaterol hydrochloride on performance and carcass traits of finishing beef steers. J. Anim. Sci. 88:338-348.
Houseknecht, K. L., C. Z. Baile, R. L. Matteri, and M. C. Spurlock. 1998. The biology of leptin: A review. J. Anim. Sci. 76:1405-1420.

Kononoff, P. J., H. M. Deobald, E. L. Stewart, A. D. Laycock, and F. L. S. Marquess. 2005. The effect of a leptin single nucleotide polymorphism on quality grade, yield grade and carcass weight of beef cattle. J. Anim. Sci. 83:927-932.

McEvers, T. J., W. T. Nichols, J. P. Hutcheson, M. D. Edmonds, and T. E. Lawrence. 2012. Feeding performance, carcass characteristics, and tenderness attributes of steers sorted by the Igenity tenderness panel and fed zilpaterol hydrochloride. J. Anim. Sci. 90:4140-4147.

Mersmann, H. J. 1998. Overview of the effects of beta-adrenergic agonists on animal growth including mechanisms of action. J. Anim. Sci. 76:160-172.

Minokoshi, Y., Y. Kim, O. D. Peroni, L. Fryer, C. Müller, D. Carling, and B. Kahn. 2002. Leptin stimulates fatty-acid oxidation by activating AMP-activated protein kinase. Nature 415:339-343.

Montgomery, J. L., C. R. Krehbiel, J. J. Cranston, D. A. Yates, J. P. Hutcheson, W. T. Nichols, M. N. Streeter, D. T. Bechtol, E. Johnson, T. TerHune, and T. H. Montgomery. 2009a. Dietary zilpaterol hydrochloride. I. Feedlot performance and carcass traits of steers and heifers. J. Anim. Sci. 87:1374-1383.

Montgomery, J. L., C. R. Krehbiel, J. J. Cranston, D. A. Yates, J. P. Hutcheson, W. T. Nichols, M. N. Streeter, R. S. Swingle, and T. H. Montgomery. 2009b. Effects of dietary zilpaterol hydrochloride on feedlot performance and carcass characteristics of beef steers fed with and without monensin and tylosin. J. Anim. Sci. 87:1013-1023.

Nkrumah, J. D., C. Li, J. B. Basarab, S. Guercio, Y. Meng, B. Murdoch, C. Hansen, and S. S. Moore. 2004. Association of a single nucleotide polymorphism in the bovine leptin gene with feed intake, feed efficiency, growth, feeding behavior, carcass quality and body composition. Can. J. Anim. Sci. 84:211-219.

NRC. 1996. Nutrient requirements of beef cattle. 7th ed. Natl. Acad. Press, Washington, DC.

Perkins, T. L., R. D. Green, K. E. Hamlin, H. H. Shepard, and M. F. Miller. 1992. Ultrasonic prediction of carcass merit in beef cattle: Evaluation of technician effects on ultrasonic estimates of carcass fat thickness and longissimus muscle area. J. Anim. Sci. 70:2758-2765.

Scramlin, S. M., W. J. Platter, R. A. Gomez, W. T. Choat, F. K. McKeith, and J. Killefer. 2010. Comparative effects of ractopamin hydrochloride and zilpaterol hydrochloride in growth performance, carcass traits, and longissimus tenderness of finishing steers. J. Anim. Sci. 88:1823-1829.

Tedeschi, L. O., D. G. Fox, and P. J. Guiroy. 2004. A decision support system to improve individual cattle management. 1. A mechanistic, dynamic model for animal growth. Agric. Syst. 79:171-204.

Tokach, R. J., K. Y. Chung, and B. J. Johnson. 2010. Zilpaterol HCL induced phosphorylation of adenosine monophosphate-activated protein kinase $\alpha$ (AMPK $\alpha$ ) in the bovine muscle cell cultures. Meat Sci. 86:575 (Abstr.).

USDA. 1997. Official United States standards for grades of carcass beef. Agric. Market Serv., USDA, Washington, DC.

Vasconcelos, J. T., R. J. Rathmann, R. R. Reuter, J. Leibovich, J. P. McMeniman, K. E. Hales, T. L. Covey, M. F. Miller, W. T. Nichols, and M. L. Galyean. 2008. Effects of duration of zilpaterol hydrochloride feeding and days on the finishing diet on feedlot cattle performance and carcass traits. J. Anim. Sci. 86:2005-2010. 